\title{
Causes, Consequences and Impact of the Great Leap Forward in China
}

\author{
Hsiung-Shen Jung ${ }^{1}$, Jui-Lung Chen ${ }^{2}$ \\ ${ }^{1}$ Department of Applied Japanese, Aletheia University, Taiwan, R.O.C. \\ ${ }^{2}$ Department of Business Administration, National Chin-Yi University of Technology, Taiwan, R.O.C. \\ Correspondence: Jui-Lung Chen, Department of Business Administration, National Chin-Yi University of \\ Technology, Taiwan, R.O.C. E-mail: leonchen@ncut.edu.tw
}

Received: March 23, 2019

Accepted: May 1, 2019

Online Published: July 10, 2019

doi:10.5539/ach.v11n2p58

URL: https://doi.org/10.5539/ach.v11n2p58

\begin{abstract}
The founding of the People's Republic of China did not put an end to the political struggle of the Communist Party of China (CPC), whose policies on economic development still featured political motivation. China launched the Great Leap Forward Movement from the late 1950s to the early 1960s, in hope of modernizing its economy. Why this movement was initiated and how it evolved subsequently were affected by manifold reasons, such as the aspiration to rapid revolutionary victory, the mistakes caused by highly centralized decision-making, and the impact exerted by the Soviet Union. However, the movement was plagued by the nationwide famine that claimed tens of millions of lives. Thus, fueled by the Forging Ahead Strategy advocated by Mao Zedong, the Great Leap Forward that was influenced by political factors not only ended up with utter failure, but also deteriorated the previously sluggish economy to such an extent that the future economic, political and social development was severely damaged. This study will explore the causes, consequences and impact of the Great Leap Forward in China.
\end{abstract}

Keywords: Great Leap Forward, Highly Centralized Decision-Making, Forging Ahead Strategy, Mao Zedong

\section{Introduction}

The Great Leap Forward Movement began at the Second Session of the Eighth National Congress of the CPC in May 1958. The Great Leap Forward Movement included "the general approach of building socialism", "Great Leap Forward" and "people's commune", thus earning the name of "Three Red Flags Movement". The movement emerged as a product of the "general approach of building socialism", the core of which, namely the slogan of "much, fast, good and saving", was proposed in the second half of 1955 and quickly implemented in the work nationwide. In around October 1957, the Central Committee of the CPC made a clear arrangement for the Great Leap Forward Movement. The rapid emergence of such movement in agriculture catalyzed the same movement in industry. The "Great Leap Forward" movement in agriculture and industry also promoted such movement in a wide range of fronts, such as transportation, commerce, culture, education and healthcare. Due to the insufficient experience of socialism and the consequent poor understanding of the laws of economic development and the basic situation of China's economy, the Great Leap Forward Movement was directly related to the criticism against the "anti-leap forward" approach. After PRC was founded, the whole country was so eager to achieve success that Mao Zedong prioritized the rapid economic development since 1953. In the absence of foreign aid and with internal struggle, the Great Leap Forward Movement failed in the PRC that was founded for less than 10 years, which triggered a hugely negative impact on China's economy at that time and later. The subsequent Cultural Revolution was launched by Mao Zedong who aimed to purge dissidents and consolidate his authority. In addition to the economic loss that was severer than that of the Great Leap Forward, the Cultural Revolution also caused great political turmoil that resulted in social unrest, educational stagnation, talent gap and waste of human resources. Most scholars have attributed the failure of the Great Leap Forward to policy errors, which were not acknowledged by Mao Zedong who even sent the economy and people of China to a deeper dilemma by eliminating dissents in the Cultural Revolution.

The Great Leap Forward was the product of multiple interactive factors, among which the international environment then merited attention. From the perspective of China, it adopted the strategy of prioritizing heavy industry because regular development could no longer meet the needs of extracting agricultural surplus in the 
Forging Ahead Strategy. Externally the blockade of imperialism, the excessive desire of the socialist camp to surpass its capitalist counterpart, and the deterioration of the relations between (the Communist Parties of China and the Soviet Union led to the Great Leap Forward. The precise analysis and judgment of the international situation lay foundation for the correct approaches, principles and policies on socialism; socialist modernization should invariably adhere to the two-pronged principle of independence and opening up; economic development must follow its own inherent objective laws (Yu, 2004). Yang (2005) pointed out that the "Great Leap Forward" was a socialist philosophy of development deviating from the right track and fueled by the sole pursuit of instant benefit; essentially the movement fantasized about breaking away from objective laws and realizing the great socialist advance merely through subjective will; its basic form was to launch mass movements that violated the law of development and the people-centered approach, resulting in disastrous consequences. Given that the discussion on the causes of the Great Leap Forward Movement is of great practical significance to the socialism with Chinese characteristics, this study is to explore the causes, consequences and impact of the Great Leap Forward Movement in China.

\section{Literature Review}

\subsection{Adoption of the Forging Ahead Strategy}

Jiao (2000) pointed out that Sun Yat-sen, Mao Zedong and Deng Xiaoping all carried out the Forging Ahead Strategy in Chinese history. Sun Yat-sen lived in an era when the Chinese nation was haunted by repeated crises and internal and external difficulties; Mao Zedong's era was characterized by wars and revolutions; Deng Xiaoping's era featured opportune timing, geographical convenience and good human relationship. Wang (2005) indicated that the national security threatened by the Korean Peninsula War and the blockade and embargo by the West on China's economy directly motivated China to adopt the Forging Ahead Strategy. The priority to heavy industry development in the first Five-Year Plan aimed to bridge the gap between the industry of China and that of developed countries immediately. The grain exports were 2,092,600 tons in the year before the Great Leap Forward (1957), 2,883,400 tons in 1958, and amounted to 4,157,500 tons in 1959. Despite the decline to $2,720,400$ tons in 1960 , the grain exports during the three-year famine were still significant. As regards grain imports, the statistics were $166,800,223,500,2,000$ and 66,300 tons from 1957 to 1960 , and the number soared to $5,809,700,4,923,000,5,952,000$ and $6,570,100$ tons from 1961 to 1964. Apart from the declining conventional food supply, Liu (2010) added another six causes to explain the Great Famine: (1) public canteen; Chang and Wen $(1997,1998)$ argued that the public canteen system eliminated household kitchens and collectivized farmers' grain stocks, so a large number of free riders should be held accountable for the food over-consumption that triggered the famine in 1958; (2) priority to urban areas: Kung and Lin (2003) used the rate of food purchase as an indicator to measure the policies inclined to urban areas. According to these two researchers, the urban population during the Great Leap Forward grew at such breakneck speed that the central government had to purchase more grain from rural areas to satisfy the food demand of the growing urban population; (3) Areas of food deficiency: Fan and Meng $(2006,2007)$ held that under the system of unified purchase and marketing, urban residents were the first social group to guarantee food supply institutionally, followed by the people of areas of food deficiency. The residents of major food production areas were least taken into account in terms of food assurance, so they were the most vulnerable to famine when the grain production fell; (4) Political radicalism: Kung and Lin (2003) held that the leaders of the southern region, more desperate to show their loyalty to the central government, were more inclined to implement radical policies than their northern counterparts; (5) governmental capacity of disaster relief: Chou (2003) said that despite the intensified effort made by provinces to increase the amount of returned grain, a string of political factors, such as pro-exaggeration and anti-rightism, had downplayed such response and relief; besides, some provinces with high mortality rate kept dispatching large quantities of grain in the height of famine, indicating that most provinces did not receive grain from the central government or other provinces despite having known what was going on and distributed returned grain for famine relief; (6) "historical memory" of the famine: Tsao (2005) indicated that people in the famine-hit areas, ranging from the civil population to local grass-roots officials, paid much more attention to grain than those in areas without famine. Therefore, these famine-hit areas did not exaggerate the grain production in the Great Leap Forward, thus dissolving the great pressure of compulsory grain acquisition by superior governments and alleviating the food shortage during the famine.

Regarding the causes for China's adoption of the Forging Ahead Strategy, the author summarizes the points of view by Liu (2000) as follows: (1) This is an inherent requirement to overcome internal pressure and immediately develop the Chinese economy of poor foundation; (2) It is an external need to tackle external pressure, rapidly shorten the economic gap between China and advanced countries, and shatter the Western policies of isolation, siege and blockade; (3) China boasted advantages in population and resources and the 
superiority of the socialist system; (4) The national economy was restored in 1952, a mere three years after the founding of the People's Republic of China; the confidence of the Chinese nation was hugely bolstered by the victorious Korean Peninsula War (resisting the United States while aiding DPRK), successful land reform and repression on counter-revolutionaries and a series of counter-revolutionary elements; (5) The rapid economic development of socialist countries fueled by the Forging Ahead Strategy, such as the Soviet Union and Eastern Europe, catalyzed China's imitation of their socialist partners; (6) China lacked in the experience of large-scale economic development and overlooked the objective economic laws. The partial emphasis on human subjective initiative prompted China to take the Forging Ahead Strategy and even endeavor reduce the time of "Forging Ahead"; (7) The consciousness of small producers, the majority of whom were farmers, prevailed in the Chinese society, laying a solid massive and ideological basis for China's Forging Ahead Strategy; (8) Mao Zedong was ambitious; (9) Mao Zedong's subjectivism and personal arbitration; (10) Mao Zedong's poetry temperament and romantic sentiment. Huang (1989) held that in order to achieve the goals set by the "Forging Ahead" strategy, the following basic relationships in specific policies should be well addressed: 1) the relationship between reform and development; 2) between accumulation and consumption; 3) between speed and efficiency; 4) between basic industry and processing industry; 5) between economic investment and educational investment; 6) between self-reliance and opening up.

In view of the 10 points of view raised of Liu (2000), the author agrees to some of them. The author gives credit to the first two opinions, (1) overcoming internal pressure and (2) overcoming external pressure, in that these two measures were necessary given what was occurring at that time. (3) Although population and resources were indeed advantages of China, but at the end of 1978 Deng Xiaoping abandoned the 30-year socialism and turned to reform and opening up and market economy, which proved that the socialist system did not boast superiority. (4) The military victory in resisting the United States and aiding the DPRK did not gain benefit from foreign countries. Instead the intensifying hostility against the West cut off the introduction of funds and technology. The negative side of the political victory showed that movements caused serious internal friction. (5) Even if the Forging Ahead Strategy of Soviet Union and Eastern Europe prompted China's imitation, the antagonism against the Soviet Union deprived China of aids received by other socialist countries in Eastern Europe. (6) The lack of experience, neglect of objective laws, partially subjective Forging Ahead Strategy and the desire to shorten the process demonstrated policy errors and exaggeration. (7) The massive and ideological foundations of small producers with peasants as the main body served as a breeding ground for the autocratic system. (8) and (9) displayed the autocratic arbitration of the dictator. (10) is Liu's personal view.

Mao Zedong first expressed this idea clearly at the National Congress of the CPC in March 1955, where he proposed to catch up with or surpass the most powerful capitalist country in the world in a few decades. At the preparatory meeting for the Eighth National Congress of the CPC in August 1956, he affirmed, "We trail the United States by 60 years. We will surpass them in 50 or 60 years. This is a responsibility." Mao also repeated similar words at the end of 1956 and 1957. In November 1957, Mao led a delegation of the CPC to Moscow for a conference of representatives of the Communist Party and the Workers' Party of all countries. During the meeting, when Mao heard Khrushchev's proposal that the Soviet Union should catch up with and surpass the United States in 15 years, he changed his original rhetoric and proposed that China should take around 15 years to surpass Britain in steel and major industrial products. On December 2, the $8^{\text {th }}$ National Congress of Trade Unions was convened, where Liu Shaoqi, on behalf of the CPC Central Committee, announced the vision of catching up with Britain proposed by Mao in Moscow. In 1958, the slogan of catching up with Britain was loud during the Great Leap Forward, and the time for this goal was continuously shortened, along with the target extended to Britain and the United States. In the second session of the $8^{\text {th }}$ National Congress in May 1958, Li Fuchun proposed: "seven years for Britain, 15 years for the United States". Then Mao revised the slogan as "seven years to catch up with Britain, plus eight or ten years to catch up with the United States". On June 22, Mao Zedong commented in a report submitted by Bo Yibo that "instead of 15 years or seven years, it will take only two to three years to surpass Britain. Possibly in two years (Chi \& Wang, 2000)."

Here are the comments by Chi and Wang (2000) on Mao Zedong's Forging Ahead Strategy: 1) The strategy was beyond China's reach; 2) Without a reference, it was difficult to show the economic strength by taking only several indicators, such as steel, as the target of catching up with Britain and the United States; 3) It is not advisable to pursue a sensational outcome in a short period of time, not advisable even at a temporarily high speed, because taking steel as the main approach with scarce external aids was bound to ruin the comprehensive economic balance; 4) The purpose of the Forging Ahead Strategy originally aimed to make the country and its people prosperous, but only the former was stressed while the latter was overlooked. The excessive emphasis on catching up and surpassing greatly hindered the improvement of living standards. 
Hsu (2004) holds that: (1) China then launched the Great Leap Forward due to the twofold needs to catch up with the Western developed countries and transform the economic impoverishment and backwardness rapidly; (2) The tide of "Forging Ahead", along with the new changes of the two antagonist camps in the international communist movement, exerted a significant impact on Mao's decision to take on the Forging Ahead Strategy; (3) The ahead-of-schedule completion of the socialist transformation of means of production and ownership and the successful First Five-Year Plan served as testament to the CPC's capacity of leading the people to win the new democratic revolution and also to gain the victory of the socialist revolution and development. According to Xu Jingong, in the goose-shaped development of Asia after World War II, China's "Forging Ahead" was after Japan, NIES and ASEAN. Therefore, Mao Zedong's "Forging Ahead" was not successful, but Deng Xiaoping's succeeded, before which China could not be incorporated into the goose-shaped theory.

The literature review shows that the decision to adopt the Forging Ahead Strategy was made in an external environment of the Western pressure and the successful experience of the Soviet Union and Eastern Europe; this strategy was fueled by the overconfidence generated in the successful completion of the First Five-Year plan. However, the uncertain time limit of the "Forging Ahead" and the fixed indicators to measure the movement demonstrated the roughness of the policy.

\subsection{Launching and Failure of the Great Leap Forward}

From 11 to January 22, 1958, the CPC Central Committee held a working meeting in Nanning, Guangxi, which unleashed the Great Leap Forward. From March 9 to 26, 1958, the CPC Central Committee convened a Political Bureau Meeting in Chengdu where high speed was determined as an indicator for the Great Leap Forward. From May 5 to 23, the Second Session of the Eighth National Congress of the CPC was convened in Beijing, establishing the guiding ideology of the Great Leap Forward. From August 17 to 30, the CPC Central Political Bureau Meeting was held in Beidaihe to push the Great Leap Forward to its peak (Lo \& Su, 2006).

In 1955, Mao Zedong advocated catching up with the United States in iron and steel production in 50 to 60 years. However, stimulated by his meeting with Khrushchev in the Soviet Union in 1957, Mao changed the schedule and launched the Great Leap Forward that aimed to surpass Britain in 15 years (Hu, 2011). Nevertheless, $\mathrm{Wu}$ (2001) believed that Mao's speech in Moscow was not a cause for the ideological changes in the "Forging Ahead". On the one hand, Mao was too excited and emotional when he presented this idea inspired by the Soviet Union's ambition to surpass the United States in 15 years. On the other hand, Mao did not propose this idea groundlessly or blindly. He based his idea on: (1) the comparison between the growth rate of China's steel output and that of Britain; (2) experience and aid offered by the Soviet Union; (3) the Chinese people's aspiration to economic prosperity. Thus, Bo Yibo did not consider reckless the goal of catching up with Britain in 15 years in terms of total steel output. According to the data available at that time, in 1972 (15 years later), the steel output of Britain was estimated to reach 36 million tons, while that of China was expected to amount to 40 to 45 million tons. In practice, the steel output of Britain reached 28.22 million tons in 1970 but dropped to 22.32 million tons in 1972. After the three-year "Great Leap Forward", China's steel output surpassed 18.66 million tons, but dropped sharply to 6.67 million tons in 1962. After adjustment, the steel output of China rebounded to 23.38 million tons in 1972. This gap indicates that without the Great Leap Forward, China's steel output in 1972 could have surpassed that of Britain easily. Mao's goal of catching up with Britain in 15 years was not impossible (Wu, 2001).

In August 1958, the Political Bureau of the Central Committee of the CPC held an expanded meeting in Beidaihe, where it was decided that the steel output in 1958 should double that of 1957 to 10.7 million tons and reach 27-30 million tons in 1959. After the meeting, a nationwide massive movement for steelmaking was launched. It was estimated that the subsidies for small blast furnaces in 1958 alone reached CNY 4 billion exceeding one-tenth of the fiscal revenue (only CNY 38.76 billion) (Bo, 1993). By the end of 1958, a total of 11.08 million tons of steel had been produced, of which only 8 million tons were qualified (Bo, 1993). On August 29, 1958, the Central Committee of the CPC convened the Beidaihe Conference, where the resolution of "establishing rural people's commune" revised and edited by Mao Zedong was passed. According to this resolution, the central government explicitly ordered a massive movement through large-scale debates and extensive participation of people. The movement of large-scale people's commune swept across China. By the end of September of that year, over 740,000 agricultural cooperatives nationwide had been merged into 23,284 "people's communes" (Bo, 1993).

Chien (2008) indicated that the Great Leap Forward Movement was an economic development movement haunted by overall failures in China's effort to explore its socialist path. At that time, the mentality of "Forging Ahead" became a momentum that merited attention, driving people to become increasingly irrational and 
deviating from the conventional track. In practice, the trend of "Forging Ahead" was so intense that it ultimately went to extreme. The lessons left by this movement are profound enough to remind people not to repeat the previous mistakes, and have also inspire China's economic development, especially the current one. The people's commune was an important part of the Great Leap Forward advocated and promoted by Mao, in that the people's commune was in line with how Mao perceived socialism. The commune was a historical derivative of the Great Leap Forward, and also a form of social organization that was necessary to ensure the practice of the Great Leap Forward (Kuan, 2002). According to Kuan, the early "People's Commune" had the following characteristics: (1) large scale; (2) high degree of public ownership and elimination of privatization; (3) unity of government and commune, extensive scope and great authority of management; (4) militarized institution, collectivization of daily life; (5) rationing system that combined the supply system with the wage system (Kuan, 2002).

The entire Great Leap Forward Movement was launched in the form of massive movement, because Mao was convinced that in doing so China's economy would develop faster and better than that of the Soviet Union. However, such massive movement proved to exert a negative impact on many aspects of the Great Leap Forward (Li, 2009). The Great Leap Forward was triggered by the underdeveloped socialist planned economy adopted by China at that time. The more economically underdeveloped a country is, the greater the internal and external pressures exist. The Great Leap Forward occurred against this backdrop. The Utopian ideas widely existing in all social strata, intense dishonesty, and demographic pressure brought about by traditional fertility concepts had a significant impact on the launching of the Great Leap Forward. Utopian ideas are the theoretical basis of the Great Leap Forward. Basically, in the dishonest social atmosphere, the farce of the Great Leap Forward led the country into disaster, and population pressure affected the formation of the Great Leap Forward to a certain extent. As regards the reasons for the failure of the Great Leap Forward, Wada (2001) summarized the following three: (1) hot-head guideline caused by problematic policies; (2) declining grain output due to successive disasters; (3) abolition of collaboration and decreasing output generated by deteriorating relations with partners. Over 40 million people starved to death statistically. Pei (2008) gave five reasons for the famine: (1) low productivity due to unfairness; (2) scruples for proposing rational opinions due to political movements; (3) reduced grain production due to increasing output of iron and steel; (4) insufficient local food supply due to grain purchase by the central government; (5) deficient food supply due to over-export. Liu (2010) argued that the main reasons for the food shortage of farmers included: (1) compulsory public canteen system, (2) governmental grain acquisition in favor of urban areas; (3) high collective accumulation of "people's communes".

After 1960, due to natural disasters and the withdrawal of experts sent by the Soviet Union, the slogan of "surpassing Britain and catching up with the United States" died down. In May 1960, when Montgomery, General of the British Army, visited China, Mao told him that "building a strong socialist economy in China will take 100 years or more, 50 years will be impossible". In January 1962, Mao Zedong pointed out at the expanded Central Working Conference that due to the huge population, weak foundation and backward economy, it seems impossible for China to catch up with and surpass the most advanced capitalist countries in the world in less than a hundred years (Chi \& Wang, 2000). Although Mao's remarks could not be considered the recognition of failure, they indicated that Mao deemed the Great Leap Forward as a reckless move.

Li (2009) indicated that the Great Leap Forward Movement was a serious mistake made by the CPC in exploring the path of socialism. The main causes for the Great Leap Forward Movement were as follows: since the founding of the PRC, the leaders of the Central Committee of the CPC headed by Mao Zedong and the people nationwide were excessively eager to achieve success, resulting in their improper criticism on the "anti-leap forward" opinions; the highly centralized leadership system was problematic; mirroring the mode of the Soviet Union, China intended to shake off the influence of the Soviet Union and explored a Chinese-style socialist approach. During the famine caused by the Great Leap Forward, the government's exporting a large amount of grain without import was the best portrayal of policy errors. The Great Leap Forward caused the industrial retrogression because of the failure of the nationwide steelmaking, which also dragged down the progress of agricultural production plans. The failure of the people's commune triggered the severe famine. The failure of the Great Leap Forward was obviously a man-made disaster, but the government attributed it to natural calamity. In 1962, Mao Zedong kept affirming the general "leftish" approach at the expanded working conference of the Central Committee of the CPC attended by over 7,000 people. Therefore, democratic centralism, not implemented properly, focused more on centralization without democracy, leading to the eruption of the Cultural Revolution (Pang \& Chin, 2003). Deng Xiaoping's success in "Forging Ahead" resided in the access to capital and technologies of advanced countries, the scarcity of which explained for Mao's failure of the same strategy. Besides, Mao's failure could also be attributed to internal factors (low-efficient and erroneous policies). 


\section{Impact of the Great Leap Forward}

Some researchers believe that the Great Leap Forward ruined the economy by shattering its overall balance. Some hold that the serious consequences of the Great Leap Forward should not be confined to the direct economic losses of up to RMB 120 billion. After the Great Leap Forward, it took five years to adjust the national economy before it was restored to the 1957 level. In the middle of and after the Great Leap Forward, Mao remained reluctant to fully acknowledge the mistakes of the Great Leap Forward and took the attitude towards the Great Leap Forward as a criterion to tell whether people were revolutionary or not. Thus, in the 10th Plenary Session of the 8th Central Committee of the CPC, he proposed the Party's fundamental approach in the socialist stage, followed by a left-wing socialist educational campaign aimed at cracking down on the capitalist roaders. This campaign resulted in the undue repression on a large number of grass-roots officials and the subsequent Cultural Revolution (Hsieh, 1995).

In the expanded working conference of the CPC Central Committee attended by over 7,000 people in 1958, Liu Shaoqi, instructed by Mao, made an oral report in addition to a written one as instructed by Mao Zedong. However, the drawbacks and errors of the Great Leap Forward acknowledged in the oral report were more serious than those in the written one, and the former clearly stated that the main culprit for the famine in many places was man-made disasters while natural disasters only made it worse. These words greatly displeased Mao Zedong. Liu was so brave that he uttered the truth and criticized the "Great Leap Forward" launched by Mao; Deng Xiaoping was kind and pragmatic. Not outspoken, he had never tried to justify Mao's "Three Red Flags"; Zhou Enlai took the big picture in mind and strictly reflected himself; while keeping Mao's authority intact; Zhou honestly faced the national difficulties without being afraid to tell the truth. Among the high-ranking leaders, Lin Biao deviated from others by boasting Mao's "Three Red Flags" and portraying Mao as the embodiment of truth. According to Lin's rhetoric, all the mistakes and drawbacks during the Great Leap Forward should be attributed to the inability to grasp and implement Mao's ideas and instructions. Encouraged by Lin, Mao was even more reluctant to reflect on himself and held a grudge against Liu, marking the preface to the Cultural Revolution (Chang, 2006).

After the Cultural Revolution was launched in 1966, the management system was ruined, labor discipline was absent, planning and statistics system collapsed, and the rampant Red Guards and armed conflict by the worker class paralyzed production and traffic. As a result, the total losses of national income in that decade amounted to approximately RMB 500 billion (Chu, 1985). In addition to the substantial economic losses, Tsai and Dou (2003) revealed that the Cultural Revolution had a great impact on the human resources in the upcoming years. For example, the average length of education of the population over 15 years old in 1982 was 4.8 years. Eliminating some of the effects caused by the Cultural Revolution, this figure was estimated to be 5.6 years, meaning that the Cultural Revolution cut the potential human resources stock by $14.3 \%$ (Tsai \& Dou, 2003). In addition, the Great Leap Forward caused the break-up of the Sino-Soviet relation. Many practices and objectives of the Great Leap Forward received constant doubt and criticism from Soviet cadres and experts. Khrushchev criticized the "People's Commune" system implicitly in his report for the $21^{\text {st }}$ National Congress of the Soviet Communist Party. In early June 1960, the CPC publicly distributed materials criticizing the Soviet Communist Party at the World Trade Union Conference in an attempt to force the Soviet Union to correct its mistakes, while the Soviet Communist Party sieged the CPC delegation in Bucharest in late June, with the purpose of subjecting the CPC to compliance. As neither side was ready to compromise, Nikita Khrushchev announced that he would withdraw all Soviet experts working in China within a time limit, bringing the antagonism between China and the Soviet Union known to the public. The dialogue between the Communist Parties of China and the Soviet Union in July 1963 showed once again that there was no room for compromise between China and the Soviet Union. The breakdown of the Sino-Soviet Union relation was irrecoverable (Shen, 2005). In a word, the Great Leap Forward had caused negative effects on the politics, economy, society and culture in China, and resulted in the loss of economic and technical assistances by foreign countries. Internationally the loss of support by the Soviet Union made the situation even more difficult for China.

\section{Conclusions}

After PRC was founded in 1949, it was plagued by various economic difficulties, but it involved in the Korean War the following year. China, claiming victory in the Korean War, received no benefit and even raised the hostility of the West, thus cutting the access to external technologies and fund. Many struggle movements were launched in China, which caused political chaos, economic losses and social unrest. The Great Leap Forward Movement fueled by Mao Zedong's strategy of "catching up with Britain and surpassing the United States" 
ended up with great economic recession and even political struggle. The Great Leap Forward, which invested colossal resources in the whole country, proved to an utter failure. Following the movement, the famine killed tens of millions of people. The decade-long political storm hit the politics, economy and society severely. During the three-year Great Leap Forward, China's science and technology movement experienced a special period of "Great Leap Forward". This was a process of initial preparation and mobilization, strong competition in all walks of life and the upsurge of the leap forward tide. Encouraged by the idea of "Forging Ahead" during the "Great Leap Forward", the science and technology in China marked a new chapter in the history. This movement paved the way for China's science and technology, and also contributed to its smooth development.

Liu (2010) listed the causes of the famine, such as the decline of traditional food supply, public canteen, orientation to urban areas and areas of food shortage, political radicalism, governmental disaster relief capacity, and "historical memory" of famine. Opinions vary among scholars who hold different arguments. In addition, according to the 1981 China Economic Yearbook, the grain exports in the year before the Great Leap Forward (1957) and during the three-year famine (1958-1960) were maintained between 2 to 4 million tons. Therefore, the erroneous export during the famine was caused by human errors instead of by natural calamity. As Chi and Wang (2000) pointed out, the industrial failure lied in the fact that only a few indicators such as steel were set as the goal to catch up with Britain and surpass the United States, which could hardly show economic superiority. The priority given to steel and the movement without external aids were bound to undermine the comprehensive economic balance.

The "Great Leap Forward" inspired by Mao's Forging Ahead Strategy was originally an economic topic. At first, the failure of the movement triggered famine, but eventually it evolved into Cultural Revolution, becoming a political or even military problem. Wang (2002) held that Mao's "Great Leap Forward" was based on his intention to get rid of the framework of the Soviet socialist model and "break a Chinese-style way". The experience of previous revolutionary victories made him regard "the masses and class struggle" as the correct way to develop socialism with Chinese characteristics. Historically Mao Zedong had achieved brilliant victories in the attempt to localize Marxism in China, but he also experienced severe failures such as the Great Leap Forward and the subsequent "Cultural Revolution", which contain profound experience and lessons. To sum up the causes for the failure of the Great Leap Forward, external factors include a world in the cold war and the absence of advanced technologies and funds provided by the West; internal factors include the incalculable adverse effects under erroneous policies. In addition, the relationship with the Soviet Union broke up, due to the disagreement between the views of China and the Soviet Union on the Great Leap Forward, resulted in the disruption of fund and technologies provided by the Soviet Union. The withdrawal of Soviet aids hindered China's economy, which had found itself in predicament, from further development for a very long time. These were tangible harm caused by the Great Leap Forward. Besides, seemingly invisible, the severely negative impact on China in all aspects lies in the talent gap caused by the 10-year Cultural Revolution. During this turbulent decade, students at all levels were deprived of the right to receive education. This erroneous policy not only afflicted the economy, but also caused great losses in culture, education, politics and military.

\section{Conflict of interests}

The authors declare that there is no conflict of interests regarding the publication of this paper.

\section{References}

Bo, Y. B. (1993). Review of Several Important Decision-makings and Events. Central Party School Press.

Chang, S. H. (2006). Changing Situation: From the Beginning to the End of the Conference of 7000 Attendees (January 11 to February 7, 1962). China Youth Publishing Group.

Chi, W. A., \& Wang, C. (2000). Questions on the Research on the Forging Ahead Ideology of Mao Zedong in the 1950s. CPC History Research and Teaching, 2, 53-65.

Chien, T. R. (2008). The Thought of "Catching-up" and Overtaking "the Great Leap Forward" Period. Social Sciences Journal of Colleges of Shanxi, 4, 120-123.

Chu, H. M. (1985). Current Crisis of the CPC Regime. In Chu et al. (Ed.), Mainland China Studies (pp. 227-234). Taipei: Wunan Publishing Press.

Feng, H. C., \& Chin, C. C. (2003). Biography of Mao Zedong (1949-1976). Central Party Literature Press.

Hsieh, T. T. (1995). Remark on Studies on Great Leap Forward. Contemporary China History Studies, 2, 32-45.

Hsu, C. K. (2004). Theoretical Discussion on Mao Zedong's Strategic Thoughts of Economic Development. Journal of the Party School of CPC Xiamen Municipal Committee, 4, 28-30. 
Hu, A. K. (2011). Discussion on Mao Zedong's Dream of Surpassing the United States. Academics in China, 155, 21-23.

Huang, T. Y. (1989). China's Adoption of the Forging Ahead Strategy. Journal of Renmin University of China, 5 , 24-29.

Jiao, R. M. (2000). From Sun Yat-sen to Deng Xiaoping: Inheritance and Development of the Forging Ahead Strategy. Teaching and Research, 7, 49-56.

Kuan, H. K. (2002). People's Commune in Chinese Mainland in 1958 and Its Conceptional Origin. East Asia Studies, 33(2), 1-10.

Lee, H. P. (2009). A Brief Analysis of the Causes of the Formation of the United Front of Our Party during the Liberation War. Monthly of CPC History in Fujian, 4, 22-24.

Liu, C. K. (2000). Reasons why PRC Took the Forging Ahead Strategy. Zhe Jiang Academic Journal, 2, 76-79.

Liu, Y. (2010). A General Theory on the Causes of China $\pi$ s Great Leap Famine: An Argument on Political Rights. China Economic Quarterly, 9(3), 1177-1188.

Liu, Y. (2010). Great Leap Forward and Chinese Famine of 1958-1961: State, Collective and Peasants in Centralized System. China Economic Quarterly, 9(3), 1119-1142.

Lo, C. Y., \& Chen, L. (2006). An Analysis on the Institutional Environment at the Beginning of the "Great Leap Forward". Socialism Studies, 2, 52-55.

National Bureau Statistics (China). (2005). Compilation of Statistics of PRC from 1949-2004. Beijing: China Statistics Press.

Pei, Y. R. (2008). 40 Million People Starving to Death, From Great Leap Forward to Famine. 21Century Bimonthly, 4, 45-50.

Sheng, C. H. (2005). Direct Manifestation and Inherent Logic of Sino-Soviet Alliance's Break: An Assessment of "National Information Estimates" of CIA. International Review, 5,7-16.

Tsai, F., \& Du, Y. (2003). Destructive Effects of Cultural Revolution on Physical and Human Capital. China Economic Quarterly, 2(4), 795-806.

Wada, A. (2001). Factors for China's Economic and Political Development. Department of Comprehensive Social Information Studies of NBS, 2, 123-124. (In Japanese)

Wang, C. H. (2003). Populism and Mao Zedong: Re-evaluation of Mao Zedong's Great Leap Forward and People's Commune. Prospect \& Exploration, 1(7), 71-72.

Wang, S. L. (2005). Initial Exploration of the Forging Ahead Strategy and Its Economic and Historical Causes. CPC History Studies, 4, 95-100.

Wang, Y. Y. (2002). On MAO ZE DONG's Thought about “The Great Leap”. Collected Papers of History Studies, 4, 50-57.

Wu, H. H. (2001). Reflection on Mao Zedong's Idea of "Forging Ahead". CPC History Research and Teaching, 2, 24-26.

Yang, F. M. (2005). On "the Great Leap Forward". Journal of Weinan Teachers University, 1, 21-24.

Yu, L. (2004). The International Reason and Lesson of the Great Leap Movement. Journal of Wuhan University of Technology (Social Science Edition), 17(4), 479-482.

\section{Copyrights}

Copyright for this article is retained by the author(s), with first publication rights granted to the journal.

This is an open-access article distributed under the terms and conditions of the Creative Commons Attribution license (http://creativecommons.org/licenses/by/4.0/). 